Review

\title{
Sugarcane Industrial Byproducts as Challenges to Environmental Safety and Their Remedies: A Review
}

\author{
Qurat-Ul-Ain Raza ${ }^{1,{ }^{\dagger}}$, Muhammad Amjad Bashir ${ }^{2,+}{ }^{+}$Abdur Rehim ${ }^{1,2, *}$, Muhammad Umair Sial ${ }^{3}$, \\ Hafiz Muhammad Ali Raza ${ }^{1}$, Hafiz Muhammad Atif ${ }^{2}$, Andre F. Brito ${ }^{4}$ and Yucong Geng ${ }^{4, *}$ \\ 1 Department of Soil Science, Faculty of Agricultural Sciences and Technology, Bahauddin Zakariya University, \\ Multan 60800, Pakistan; quratulain1111@yahoo.com (Q.-U.-A.R.); maraza1524@gmail.com (H.M.A.R.) \\ 2 College of Agriculture, Bahadur Sub-Campus Layyah, Bahauddin Zakariya University, \\ Multan 60800, Pakistan; amjad.bashir941@gmail.com (M.A.B.); aatif.pak@bzu.edu.pk (H.M.A.) \\ 3 Department of Plant Protection, MNS University of Agriculture, Multan 60000, Pakistan; \\ umair.sial@mnsuam.edu.pk \\ 4 Department of Agriculture, Nutrition, and Food Systems, University of New Hampshire, \\ Durham, NH 03824, USA; andre.brito@unh.edu \\ * Correspondence: abdur.rehim@bzu.edu.pk (A.R.); tiger86gyc@gmail.com (Y.G.) \\ + The authors have contributed equally, should be considered as the first authors.
}

check for updates

Citation: Raza, Q.-U.-A.; Bashir, M.A.; Rehim, A.; Sial, M.U.; Ali Raza, H.M.; Atif, H.M.; Brito, A.F.; Geng, Y. Sugarcane Industrial Byproducts as Challenges to Environmental Safety and Their Remedies: A Review. Water 2021, 13, 3495. https://doi.org/ $10.3390 /$ w13243495

Academic Editors: John Zhou and Muhammad Faheem

Received: 14 November 2021

Accepted: 6 December 2021

Published: 8 December 2021

Publisher's Note: MDPI stays neutral with regard to jurisdictional claims in published maps and institutional affiliations.

Copyright: (c) 2021 by the authors. Licensee MDPI, Basel, Switzerland. This article is an open access article distributed under the terms and conditions of the Creative Commons Attribution (CC BY) license (https:/ / creativecommons.org/licenses/by/ $4.0 /)$.
Abstract: Sugarcane (Saccharum officinarum) is one of the major crops cultivated in tropical and sub-tropical countries, and the primary purpose is to obtain raw sugar. It is an important substance for sugar and alcohol production by both the sugar and beverage industries. During cane processing, various byproducts are obtained, namely sugarcane bagasse, bagasse ash, pressmud cake, sugarcane vinasse, and spent wash. There are many challenging problems in storage, and they cause great environmental pollution. This review discusses their properties by which they can be used for cleaner agricultural and environmental sustainability. Utilization of byproducts results in valueadded soil properties and crop yield. Replacing chemical fertilization with these organic natured byproducts not only minimizes the surplus usage of chemical fertilizers but is also cost-effective and an eco-friendly approach. The drawbacks of the long-term application of these byproducts in the agricultural ecosystem are not well documented. We conclude that the agriculture sector can dispose of sugar industry byproducts, but proper systematic disposal is needed. The need arises to arrange some seminars, meetings, and training to make the farming community aware of byproducts utilization and setting a friendly relationship between the farming community and industrialists.

Keywords: sugar industry; environmental pollution; sustainable productivity; soil properties; environment sustainability

\section{Introduction}

Sugarcane (Saccharum officinarum) is an important cash crop belonging to the family Gramineae, cultivated in tropical and sub-tropical regions of the world. About 200 countries are cultivating it, amongst which Brazil is the largest producer, contributing around $25 \%$ of the world's total production [1]. Annual cane production in Brazil, India, China, and Pakistan was 648, 348, 124, and 64 million tonnes, respectively [2]. The major use of cane is its utilization for sugar production, which contributed about $92 \%$ of cane produced [1]. Brazil, India, Australia, China, and Thailand contributed about $40 \%$ of worldwide sugar production. Amid 115 sugar-producing countries, 67 are cultivating sugarcane, 39 are using sugar beets, and 9 countries are utilizing both sources; this indicates sugarcane is about a $70 \%$ contributor to sugar production [3]. The sugar industry is also playing a key role in the economic development of Pakistan as one of the major and oldest agro-industries in the country, contributing about four billion PKR to Gross Domestic Product (GDP) [4].

In addition to sugar and beverage production, sugarcane processing industries are generating environmentally unsafe byproducts and their disposal is also a big issue [5]. 
Pressmud cake (PMC; $3.4 \%$ ) and sugarcane bagasse (SCB; $25-30 \%$ ) are key produced byproducts during sugar production. In Thailand, about 1.7-2 million tones PMC and 15-18 million tones SCB were obtained annually from 1994-2000 [6]. During the distillation of cane in alcohol production, wastewater called spent wash (SW) is obtained. About 12-15 L of spent wash is released for a liter of alcohol [7]. The release of SW in nearby watercourses by many industries results in the higher mortality rate of aquatic animals. The organic nature of SW makes it a rich source of plant-available nutrients; hence, treated SW can be used as an organic fertilizer in the agricultural industry [7]. Long-term input of untreated SW in the soil causes accumulation of toxic substances resulting in induced pollution [8].

Ethanol production also results in the release of sugarcane vinasse (SCV); processing 1-L ethanol from sugarcane releases about 10-15 L SCV [9]. In Brazil, approximately 350 working refineries are capable to produce about 16 billion liters of ethanol/year [2]. The domestic sewage discharged by a town of 1.5 lac inhabitants is equal to the direct disposal of $1000 \mathrm{~m}^{3} \mathrm{SCV}$ per day [10]. It also has important crop-required nutrients and is being used as fertilizer as well as a soil conditioner in agricultural fields [11]. The fertigation of SCV as a fertilizer source helps in controlling the addition of toxic substances in water bodies [12]. To use the byproducts as an important input in the agricultural system requires them to be treated before application. Thus, possible treatment methods in safe grains production need to identified (kind and dose of byproduct, crop-specific, and site-specific byproducts application). However, the relevant knowledge has not been well synthesized.

Here, we review the state-of-the-art knowledge for their prime role in field productivity, economic development, and suitable disposal. Particularly, we focused on important factors influencing soil nutrients status, crop productivity, and environmental sustainability. Principally, we review the effects of using sugar industry byproducts on plants and soil and shed light on the mechanism reported in this regard. We aimed to answer the following queries: What are the major sugar industry byproducts and their properties? How can they be used in the agriculture field? What are the impacts of byproducts on soil health, plant production, and the environment? What factors are involved in improving soil properties and plant yield? What environmental issues will be arising or solved using industrial wastes? What are the research queries scientists need to address in future?

The review consists of 9 sections: the introduction and background of the review (Section 1), review methodology (Section 2), needs of the organic amendments (Section 3), physico-chemical properties of sugar-industry byproducts (Section 4), effects of byproducts on crop yield and soil properties along with the mechanisms (Section 5), benefits of sugarindustry byproducts (Section 6), problems and constraints (Section 7), future aspects (Section 8), and conclusion of the review (Section 9).

\section{Review Methodology}

The scope of this article is to provide a review of an eco-friendly disposal of sugar industrial byproducts, specifically in agriculture, and to find its impact on crop yield, soil productivity, and the environment. To ensure the quality of the review, we collected peer-reviewed journal articles, review papers, books, and research reports indexed by Google Scholar, Scopus, Science Direct, and Web of Science databases. Firstly, we prepared a list of keywords related to the objectives and scope of the article. Afterward, the pool of references was identified using the keywords "sugar industry wastes", "pressmud cake", "sugarcane bagasse", "spent wash", "sugarcane vinasse", and "sugarcane byproducts". Finally, we read and identified the references by following the given criteria.

\subsection{Literature Review}

In this review, we have focused on the potential use of sugar-industry byproducts. Therefore, we do not focus on any specific byproduct and considered all the waste products eliminated by the sugar industry. This study provides basic knowledge and information to the farmers, industrialists, and practitioners related to the agro-industrial sector. Further- 
more, we selected the articles discussing the experiments using byproducts and sharing their impacts on soil, plant, and the environment.

\subsection{Selection Criteria}

To guarantee the quality of the review, we selected articles and reports published in reputed journals and organizations. Moreover, reports were excluded if they were not related to the utilization of byproducts in agriculture. Related guidelines for selection criteria were studied from previous studies [13].

- The disposal of industrial waste in agriculture and all other queries related to this objective were the priority.

- While sorting out the articles, the questions discussed in the introduction section were kept a priority.

- Excluded the data if it was not related to the agriculture and sugar industry.

- The articles not published in well-reputed journals were also excluded.

- The information for the benefits of agro-industrial sector was addressed and transformed into tables and figures.

\section{Why There Is a Need for Organic Amendments?}

The human population has been growing rapidly in the last two centuries, leading to industrial development worldwide that results in higher waste and hazardous material induction in the soil and water, causing great environmental pollution [14]. It is impossible to convert these pollution-generating industries with clean ones, but one alternative is to treat the waste and utilize it as raw material for other industries [15]. The extended population has also given rise to a big challenge to the farming community, as agricultural, and environmental scientists to find ways of cleaner production with maximum yield [16].

Intensive cropping has reduced the soil capacity to supply nutrients, which shows an incredible decline in soil fertility and damages sustainable agricultural production [17]. Alteration in physico-chemical properties of soil and deficiency of macro, micro, and secondary nutrients has reduced optimum nitrogen $(\mathrm{N})$, phosphorus $(\mathrm{P})$, and potassium (K) supply to maintain crops production. This phenomenon induced the need of identifying alternative nutrients sources [18]. The microbial population, its size, activity, and biodiversity can be enriched with appropriate organic residues [19]. Rice, wheat, and sugarcane are highly exhaustive crops and require higher nutrient inputs to enhance their production. In their cropping system, about 28 to 30 million tonnes of nutrients (NPK) are removed, whereas about 18 to 20 million tonnes are added, creating a deficiency of 10 million tonnes [18]. Study recommends the combined application of organic and inorganic nutrient sources to meet nutrient deficiency challenges, maintaining soil fertility, better soil health, and sustainable agriculture [20].

Sugarcane industries are releasing sufficient quantities of byproducts while producing sugar and beverages. These byproducts could be effective in the agricultural production system, help in environmental protection, and reduce expensive chemical fertilization [21]. Application of industrial waste to soil in agricultural production systems is considered an easy and cost-effective technique to dispose of these substances [19]. The study [22] has also reported that conversion of wastes in organic manures not only reduces the pollution but also flourishes the soils and reduces fertilizer cost. In addition, continuous application of organic substances can maintain the soil production capacity [16], fertility, and nutrient status [23].

To enhance net income for the farming community and taking up their livelihood, use of expensive chemical fertilizers should be de-emphasized and replaced with locally generated organic manures to promote sustainable agriculture [16,24]. In Asian countries, soil-water degradation and poor nutrient management have reduced the productivity in the rice-wheat cropping system [25]. In addition, the increasing demand and reduction in availability of fresh water has resulted in water scarcity. It has been reported that the agriculture sector accounts for approximately $69 \%$ of the water withdrawals [26]. 
Furthermore, agro-industries, specifically sugar-industries, are huge consumers of fresh water as well as generating huge amounts of wastewater and byproducts [27]. Therefore, proper management of wastewater can be used to tackle the water scarcity problem [28].

From sugarcane industries, SCB and PMC are highly produced wastes and have proper dispose-of problems [18]. The major products of sugarcane industries are sugar and alcohol but processing also gives rise to some nutrient-enriched byproducts that can be used as fertilizers and soil conditioners in the agricultural ecosystem [21]. These organic byproduct residues are good sources of macro and micronutrients and, when applied to soil, result in improving the soil's physical, chemical, as well as biological properties [18]. In addition, severe pollution issues might arise with the discharge of SW in water bodies. Therefore, its use as fertilizer and fertirrigation or a combination with other byproducts could be an effective practice [29].

Studies reported that PMC is highly cheaper than chemical fertilizers, has higher productivity potential, and enhanced carbon sequestration in the soil environment [19]. Its application, at the rate of 5 tonnes ha ${ }^{-1}$, has the potential of saving 60 and $40 \mathrm{~kg} \mathrm{~N}^{-1}$ in rice and wheat, respectively [20]. Composting of $3202 \mathrm{~kg}$ of PMC releases nutrients approximately equal to $502 \mathrm{~kg}$ of triple super phosphate; grain and straw yield of rice, dry matter yield, and P uptake were also comparable [18]. Vinasse application in the agricultural ecosystem improves the structure of soil, water contents, cation exchange rates, ions availability, nutrient status, microbial biodiversity, and their activity [30]. It serves as a complete fertilizer in sugarcane production [31] and is commonly being utilized as fertilizer in many countries [32] as it can improve total $\mathrm{N}$, chloride ions, humic acid, and organic matter contents in soil [33]. Distillery effluent application with NP fertilizers gave similar yields as NPK, which suggests K fertilization can be skipped with SW application [34]. Studies showed that sugarcane crops have a positive response to SCV application, and it also improves the soil properties [11]. It is also found that the combined use of SW and inorganic fertilizers (NPK) reduced the cost with sustained production [25].

\section{Physico-Chemical Properties in Sugar Industry Byproducts}

As discussed above, sugarcane-processing industries are producing different byproducts that have different storage and disposing-of issues. Their utilization in the agricultural ecosystem is also under consideration, and the release of these byproducts at different processing periods is shown in Figure 1. They are being produced at milling, purification, and fermentation stages for the production of sugarcane juice, sugar, and alcohol, respectively. Organic natured byproducts have different nutrient pools, and chemical and physical properties to influence the soil properties. The apparent variations in their looks of the mostly produced three byproducts are shown in Figure 2. Physico-chemical properties of each byproduct are discussed (Tables 1 and 2).

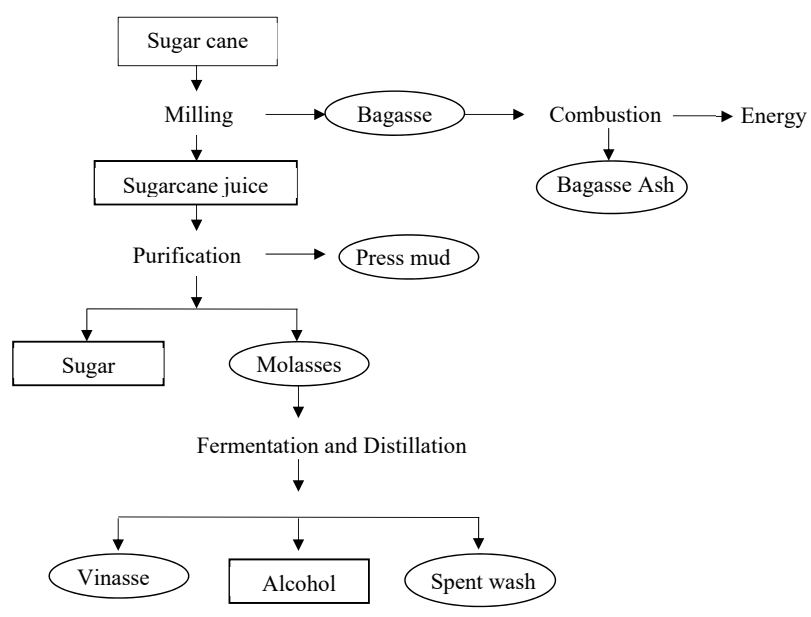

Figure 1. Flowchart of sugar and ethanol production process along with byproducts. 


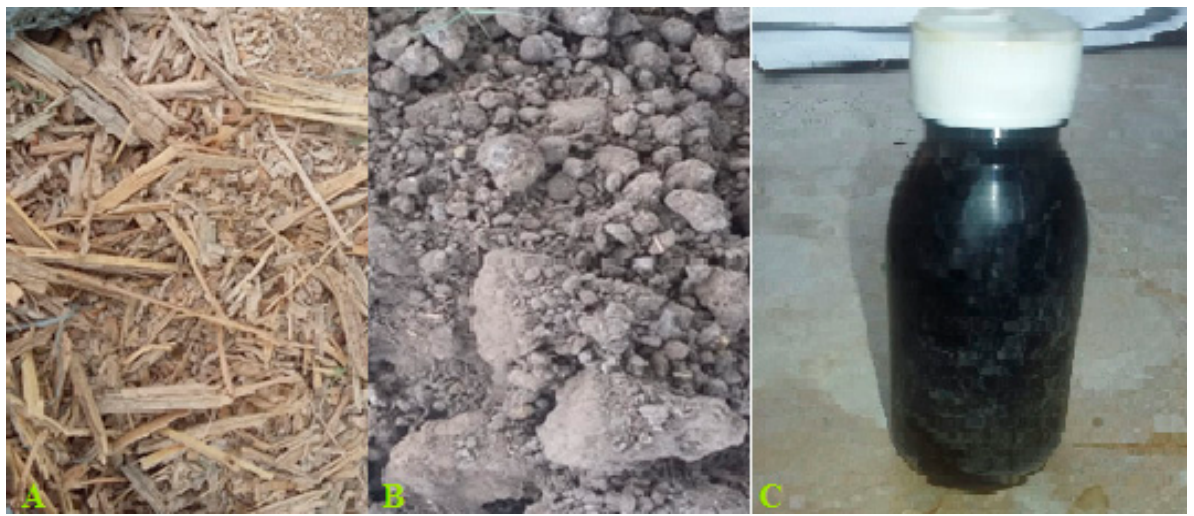

Figure 2. (A) bagasse; (B) pressmud; and (C) vinasse.

Table 1. Composition of various sugarcane byproducts.

\begin{tabular}{ccccc}
\hline Parameter & Sugarcane Bagasse & Pressmud Cake & Sugarcane Vinasse & Spent Wash \\
\hline Water & $49 \%$ & $80 \%$ & $93 \%$ & \\
Organic matter & - & $50 \%$ & $19.5 \mathrm{~g} \mathrm{~L}^{-1}$ & $3.3 \%$ \\
Nitrogen & $0.4 \%$ & $1.5-2.5 \%$ & $1190 \mathrm{mg} \mathrm{L}^{-1}$ & $225-3030 \mathrm{mg} \mathrm{L}^{-1}$ \\
Phosphorus & - & $1.8 \%$ & $120 \mathrm{mg} \mathrm{L}^{-1}$ & $9600-17,400 \mathrm{mg} \mathrm{L}^{-1}$ \\
Potassium & - & $0.9 \%$ & - & - \\
Cellulose & $50 \%$ & $11.4 \%$ & - & - \\
Hemi cellulose & $25 \%$ & $10.0 \%$ & - & - \\
Lignin & $25 \%$ & $9.3 \%$ & $3.3 \%$ & {$[41]$} \\
Ash & $2.4 \%$ & $9-10 \%$ & {$[2,39,40]$} & \\
Source & {$[35,36]$} & {$[19,37,38]$} & & \\
\hline
\end{tabular}

Table 2. Chemical characteristics of sugarcane byproducts.

\begin{tabular}{ccccc}
\hline Parameter & Sugarcane Bagasse & Pressmud Cake & Sugarcane Vinasse & Spent Wash \\
\hline $\mathrm{pH}$ & - & Acidic/alkaline & $3.5-5$ & $3.8-5$ \\
$\mathrm{EC}\left(\mathrm{dS} \mathrm{m}^{-1}\right)$ & - & - & 0.328 & 28 \\
$\mathrm{C}: \mathrm{N} \mathrm{ratio}$ & 100 & 14 & - & 15.8 \\
Source & {$[21]$} & {$[42]$} & {$[11]$} & {$[34,41,43]$} \\
\hline
\end{tabular}

Sugarcane bagasse is a cellulosic agro-industrial byproduct released after crushing and extracting juice from the canes. It is a dry, pulpy residue and is fibrous in nature [18], composed of approximately 50\% cellulose, 25\% hemicellulose and also lignin, 30\% pentosanes, and $2.4 \%$ ash [44]. It is utilized as raw material for pulp, paper, electricity, and fermentation, and is also involved in enzymes production, protein enrichment, and substrate for microorganism culture [36]. Sugar industries are discarding a large amount of SCB on a daily basis, causing different environmental problems. So, it is necessary to identify an appropriate method for its disposal as soon as possible [45].

Combustion of SCB results in the production of bagasse ash (BA). About $25 \mathrm{~kg}$ of ash is produced from each tonne of SCB. The ash does not contain an adequate amount of minerals, but it is used as fertilizer. In addition, it is also used in the construction industry as a cementing agent [46]. Pakistan sugar industries are producing an estimate of about 2.0 million tonnes BA per annum, which is a good micronutrients source [47].

The sugar industry eliminates a solid waste byproduct known as PMC. It is produced after the filtration of sugarcane juice. For every $100 \mathrm{~kg}$ sugarcane crushed, about $3 \mathrm{~kg}$ PMC is generated as waste. Being a waste product, it creates disposal issues and environmental pollution, whereas it is a rich source of nutrients such as phosphorus $(\mathrm{P})$, potassium $(\mathrm{K})$, and organic matter. Therefore, it can be used as compost for better crop productivity and improving soil physical, chemical, and biological properties [22]. In addition, it is reported 
that PMC compost contains enzymes, hormones, vitamins, and plant growth regulators that are beneficial for plant root percolation and soil aeration. Furthermore, it is free of any unfavorable substance for microbial activity [48].

Pressmud cake (PMC) is obtained from two processes: sulphitation process and carbonation process. In acidic soils, it is recommended to use PMC obtained through the sulphitation process due to its acidic nature. It contains organic matter (26\%), N (2.43\%), $\mathrm{P}(2.95 \%)$, and $\mathrm{K}(0.44 \%)$, whereas the latter one is alkaline, and thus considered good for acidic soils. Its constituents are organic matter $(15.07 \%), \mathrm{N}(0.88 \%), \mathrm{P}(0.93 \%)$, and $\mathrm{K}$ $(0.53 \%)$, respectively [18].

Moreover, PMC is soft, spongy, and dark brown. Its composition shows that it contains sugar, fiber, cane wax, inorganic salts, and soil particles. Moreover, different elements such as water, macronutrients, calcium, sulphur, and other substances are also present in varying concentrations. It is a low-cost material with effective mulching properties. In addition, it contains fibrous material that has a high water-holding capacity, and thus can be considered as a soil amendment. On the other hand, its bulky nature makes it difficult to handle and, when freshly applied, it becomes toxic to the plants by liberating a high amount of heat and ammonia due to rapid decomposition [19]. It can be beneficially used as organic fertilizer after wax extraction, as it improves the soil water holding capacity.

It is reported that PMC contains crude wax (5-14\%), fiber (15-30\%), crude protein (5-15\%), sugar (5-15\%), and total ash (9-10\%). It also consists of oxides of $\mathrm{Mg}, \mathrm{Si}, \mathrm{P}$, and $\mathrm{Ca}$ and other macronutrients [49]. It is rich in sulphate and carbonate and usually consists of lime (70\%), organic matter (15-20\%), and sugar (2-3\%) [50]. Due to complex cellulose matrix and lignin, PMC is not easily degradable, whereas different microbes such as fungi, bacteria, and some actinomycetes contribute to PMC decomposition [51]. Currently, as the farmers cannot afford the high-cost mineral fertilizer, PMC is a good source of plant nutrients.

Sugarcane vinasse has high chemical oxidation demand (COD) and low $\mathrm{pH}$. It consists of various organic compounds such as acids, ketones, esters, sugars, etc., total soluble solids $(2-4 \%)$, and has high turbidity [11]. Moreover, it also contains dry matter $(8.4 \%)$, total ash $(3.3 \%)$, crude protein $(4 \%)$, total carbohydrates $(0.95 \%)$, reducing sugar $(0.75 \%)$, $\mathrm{Na}(0.29 \%), \mathrm{K}(0.94 \%)$, water (93\%), and organic solids and minerals (7\%) [52]. In addition, SCV contains different organic compounds such as glycerol, ethanol, acetic acid, lactic acid, and organic acids such as lactate, acetate, malate, and oxalate. Moreover, phenol contents and alcoholic compounds are also present [53].

The chemical composition of SCV showed that it contains a high amount of $\mathrm{Ca}$ and K, along with moderate levels of $\mathrm{N}$. It is dark brown in color, acidic, and has an unpleasant odor [52]. Moreover, SCV is also useful in detoxification of soil impurities. Bioremediation is a process in which microorganisms or plants are used to detoxify contaminants. The microbial activity of the microbes is stimulated by the addition of nutrients. Therefore, to detoxify the soil contaminants, SCV can be used as a nutrient supplier for microorganisms [2].

The continuous application of SCV for 2-3 years reduced the soil bulk density and clay contents, enhanced the soil $\mathrm{K}$ contents, and total and capillary porosity in the sugarcane field [54]. It has also been revealed that it decreases the soil $\mathrm{pH}$ level but significantly increases the availability of $\mathrm{N}, \mathrm{Mg}$, and $\mathrm{K}$ contents in the soil [55]. Thus, using SCV as an organic amendment is a conversion of waste to wealth. Other than as an organic fertilizer, it has also been used for the production of livestock feed due to its high nutrient concentration [56].

It has high organic contents and dissolved solids that make it hazardous to the environment when directly disposed of, causing soil and water pollution [40]. When produced from sugarcane molasses, it has low $\mathrm{pH}$ and total solid contents (2 to $4 \%$ ) but high COD [11]. Moreover, SCV is a corrosive material, having high biological oxidation demand (BOD); therefore, its disposal in rivers may harm aquatic life, especially in large amounts [57]. According to some researchers, its COD is about 70,000-80,000 $\mathrm{mg} \mathrm{L}^{-1}$ and BOD is about 
45,000-65,000 $\mathrm{mg} \mathrm{L}^{-1}$ [58]. Moreover, it could also be a source of fats, oil, and grease, and thus considered unsafe [59].

Spent wash is a distillery liquid having dark brown color and an unpleasant odor [41] It is acidic in nature and has high BOD $\left(40,000\right.$ to $\left.60,000 \mathrm{mg} \mathrm{L}^{-1}\right)$ and COD $(1,00,000$ to $\left.1,20,000 \mathrm{mg} \mathrm{L}^{-1}\right)$. Moreover, it contains organic matter and plant nutrients $(\mathrm{N}, \mathrm{P}, \mathrm{K}, \mathrm{Ca}, \mathrm{Mg}$, $\mathrm{Na}$, and S) and its properties resemble humic acid [60]. The compounds present in SW are highly recalcitrant and have antioxidant properties, which might be toxic to microbes [60]. It also consists of low molecular mass bioactive substances such as hormones, humic acids, and vitamins [25]. Moreover, it has a considerable amount of Ca that makes it useful for reclamation of sodic soils [61].

The dark brown color of SW is due to melanoidin, a polymer compound. It is formed by the non-enzymatic reaction between sugar and amino compounds at high temperature. Melanoidin is about $2 \%$ of the SW by mass; however, its concentration may vary in distillery SW and sugar industrial SW [62]. With the advancement in agribusiness, the production of waste materials in agriculture and related industries is increasing day by day. Therefore, it is necessary to introduce multiple techniques to minimize and/or re-use the waste products [63].

\section{Effects of Products on Crop Yield and Soil Properties}

Sugarcane byproducts significantly impact crop yield and soil properties (Figure 3). The study [22] reported that the application of 1.25 tonnes ha $^{-1}$ enriched PMC compost reduces the mineral fertilizer requirement up to $20 \%$ for rice crop. PMC compost maximizes the crop yield and also improves the soil fertility when applied as a basal dose along with three splits of nitrogen mineral fertilizer in kharif season. Application of 6 tonnes ha ${ }^{-1}$ PMC alone and 4 tonnes ha ${ }^{-1}$ PMC along with $5 \mathrm{~kg}$ Azotobacter ha ${ }^{-1}$ both give similar results when applied in sugarcane fields [64]. It was studied [65] that PMC increases nutrients in soil and also maximizes the agronomical performance of eggplant when used in low proportion (up to $40 \%$ ).

Application of PMC along with nitrogen improves dry matter, sugarcane yield, and sugar production [66]. Moreover, PMC also contains N, and thus its excessive amount leads to the depression in cane quality [67]. The effects of PMC on soil properties include improved N, P, and Ca contents and decreased aluminum concentration [21]. It also increases the soil cation exchange capacity (CEC) and its residual effects last for 4 years [68]. As described earlier, PMC contains macro and micronutrients, and along with $21 \%$ organic carbon thus promote microbial activity and supplies plant nutrients [18].

Pressmud cake is a rich source of moisture contents, $\mathrm{P}$, and organic matter and it can be used as a complete/partial substitute for chemical fertilizers in cane crop. It is also used in composting, vermicomposting, and production of seedlings [21]. In the Midlands, an excellent response was observed when PMC was applied in large quantity as a phosphatic fertilizer in the soils having high phosphorus fixation. Distillery effluent, when incorporated with PMC, increases the plant nutrients (N, P, K, and S) due to improved microbial activity [18].

Excessive use of inorganic fertilizers decreases the nitrogen use efficiency (NUE); thus, a very large amount of $\mathrm{N}$ fertilizer will be required to fulfill the food requirement of 9.3 billion people in 2050 [69]. The study [70] concluded that the application of PMC and urea (1:3) improved the maize yield, NUE, and N uptake, as well as reduced N losses in poor soils. By applying PMC, the soil carbon sequestration rate can be boosted, along with the betterment of soil and mitigation of climate change. Moreover, organic carbon increases up to $150 \%$ after the first application when PMC is applied as organic manure, whereas a 36.36 and $30.67 \%$ increase was observed in subsequent growing seasons [19]. It also minimizes the nutrient losses through leaching and runoff as it prevents the soils from water and wind erosion [24].

Pressmud cake also increases the microbial population in soils which contributes to the organic matter decomposition and subsequently releases nutrients for plants [19]. 
The low $\mathrm{C} / \mathrm{N}$ ratio of PMC composting results in $\mathrm{N}$ losses which can be minimized by preparing a mixture compost of SCB and PMC. It has been reported that PMC added as an organic amendment at the rate of 60 tonnes ha ${ }^{-1}$ prevents weeds competition and also increases manioc crop productivity by $50 \%$ as compared to chemical fertilization [21].

In sugarcane field, when applied as a base fertilizer, SCV improves the soil fertility status and increases the sugarcane and sugar yield without causing any hazardous effects on groundwater [54]. It is revealed that the spray of SCV without any mineral fertilizer ensures good growth of sugarcane plants and also improves sucrose contents [71]. Moreover, it is responsible for increasing $\mathrm{Na}$ and manganese $(\mathrm{Mn})$ concentrations but not to toxic levels, while the increase in K levels is useful. Furthermore, the application of SCV also effects soil physico-chemical properties. It increased the concentration of $\mathrm{K}, \mathrm{Na}$, and $\mathrm{Mg}$ in soil [72]. In Spain, SCV based organic compounds were applied on beet and maize crop. Results indicate that SCV is a good alternative form for chemical fertilizers, thus reducing environmental pollution [21].

The top creepers vegetables can be cultivated using SW only and without any organic or inorganic fertilizers. Thus, it reduces the cultivation cost and upgrades the economy of farmers [73]. Application of SW (80 tonnes ha $\left.{ }^{-1}\right)+$ fertilizer (84:56:56 kg NPK ha ${ }^{-1}$ ) improved the cane production [25]. Moreover, it also increases the zinc $(\mathrm{Zn})$, copper $(\mathrm{Cu})$, $\mathrm{Mn}$, and iron uptake in wheat and maize, with lower dilution levels [73]. This study [8] revealed that it is a good source of plant nutrients as well as a sodic soil reclaiming agent. When applied at the rate of $180 \mathrm{~m}^{3} \mathrm{ha}^{-1}$, the physical, chemical, as well as biological properties of sodic soils were improved. However, it hinders seed germination due to the high sticky nature. It blocks the relationship between soil, groundwater, and plant. As time passes, its high viscosity and gravity make it percolate down to the groundwater [74].

It was concluded that the application of distillery effluent improved the soil physical properties as well as gave similar yield to that of $100 \%$ recommended NPK + manure in soybean. Thus, it can be used as a soil amendment, but in prescribed limits to avoid soil salinity development. Organic carbon, available K, saturated hydraulic conductivity, bulk density, and volumetric water content improved with effluent application [7]. There was no change in $\mathrm{pH}$ while soil EC increased which shows that it might increase the soil salinity in the long run [75].

The high concentration of SW decreases the seed germination, seedling growth, and chlorophyll contents in Brassica napus [76] and sunflower [77]. Spent wash improved the germination and growth of groundnut (VRI-2) and gingelly (CO-1) when applied at 10 and $20 \%$ dilution. It improved the biomass yield of Cumbu Napier hybrid fodder (three cuttings) when applied at the rate of $37.5 \mathrm{~m}^{3} \mathrm{ha}^{-1}$ with supplementation of recommended NP 25 and 60\% [41]. However, inappropriate discharge of SW results in soil pollution and acidification. It might disturb seed germination rate, reduce soil alkalinity, and adversely affect crop production [78].

Moreover, SW application increases the soil organic carbon and microbial biomass, and ultimately improves oil fertility status. It is a nutrient rich source for microbes and also provides energy, proteins, and sugar, which contribute to growing the microbial population and activities in soil. It also improves nutrient uptake in plants that can be associated with the improved soil properties and enzymatic activities [27].

Bagasse ash and rice husk biochar, when applied in the sandy soils of Florida, resulted in better sugarcane yield [79]. Moreover, it can be used in rice-wheat cropping systems for improved productivity with no harm to soil health [16]. Potassium partial factor productivity increased with the combined application of PMC and mineral fertilizers. Meanwhile, physiological K efficiency enhanced with the use of BA and microbial inoculant. This shows that the combined application of organic, inorganic, and biofertilizers can effectively improve the sugarcane yield along with $\mathrm{N}$ and $\mathrm{K}$ use efficiency [80]. 


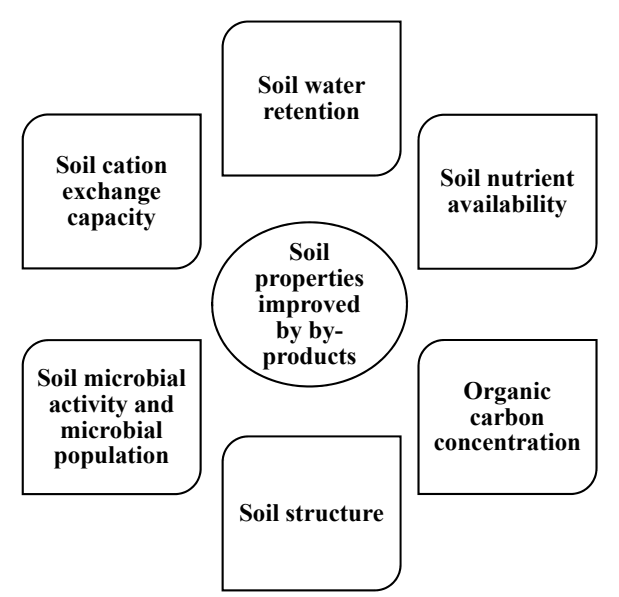

Figure 3. Effect of sugar industry byproducts on soil properties; sourced from [30,38,81].

\subsection{Mechanisms Involved in Effecting Crop Yield}

Sarwar [82] reported that the application of PMC and urea (1:1) increases the number of millable canes and cane yield as compared to PMC alone. Pressmud cake, when applied in sugarcane field, improves the growth and yield parameters, including weight and number of millable canes [18]. Moreover, it is reported that the combined application of PMC and mineral fertilizers increases the number of tillers in rice, whereas a high dose of PMC compost leads to the reduction in productive tillers [83]. It might be due to the poor mineralization of $\mathrm{N}$ at the requirement stage and soil native $\mathrm{N}$ immobilization [84].

The application of SCB and PMC decreases the soil bulk density and improves the soil macropores, which lead to better root growth, and better cane yield is ultimately attained. Moreover, plant $\mathrm{P}$ uptake from water-soluble $\mathrm{P}$ fertilizers increases due to the addition of organic acids in soil [18]. Bagasse and PMC ( $5 \mathrm{~g} \mathrm{~kg}^{-1}$ of soil), when applied in combination with rice straw, increase the P availability $(68 \%)$ and decrease the soil P fixation $(20 \%)$ [18]. Pressmud cake when applied increases the CEC of soil for 2.5 years [68].

In sugarcane fields, diluted SCV is being used by researchers as liquid fertilizer. The application showed improvement in soil properties as well as crop productivity [31]. Patil and Shinde [85] observed an increase in dry matter production of maize with the application of spent slurry PMC and SW. It has been observed that SCV concentration up to $2.5 \%$ increases the activity of growth enzymes and chlorophyll contents and protein contents of Pisum sativum and Helianthus annuus. However, its higher concentration decreases these parameters. Seed germination percentage and germination index of these crops also retard with the increase in SCV concentration [58].

Different varieties of pulses were influenced by the $33 \%$ SW irrigation. This might be due to the better nutrient absorption by plants at higher dilution of SW [77]. The higher concentrations of effluent are not recommended for irrigation as they cause toxicity due to excess nutrients. Therefore, proper dilution of effluents is required for better growth and yield [86]. Moreover, when applied to sodic soils, SW significantly improved the rice grain yield [41]. It has been reported that high $\mathrm{CO}_{2}$ evolution is due to the acidic nature of SW which significantly affects the dry matter yield of maize crop [85]. The protein percent in wheat grains increased at lower dilutions, while the opposite trend was observed in maize grains when starch percent was studied [34].

According to [87], in acidic soil conditions, PMC and BA are good nutrients sources and also correct the soil $\mathrm{pH}$. Authors also observed that BA used in a lesser amount than PMC gave higher wheat yield in low fertile soils. The application of PMC and SCV improves the soil fertility and biological properties [5]. It also contributes to enhancing the sugarcane productivity and reduces the use of chemical fertilizer. Previous studies indicate that the application of PMC improved the yield of finger millet, enhanced the wheat yield and yield components, and produced higher cane yield and stalks (Table 3). Application of 
PMC significantly improved the sweet potato yields and maize production along with the soil organic matter [88].

Table 3. Crop yield obtained using byproducts.

\begin{tabular}{ccccc}
\hline Country & Crop & Byproduct & Yield (T ha $\mathbf{~}^{\mathbf{1}}$ ) & Reference \\
\hline China & Sugarcane & Pressmud & 104.5 & {$[5]$} \\
China & Sugarcane & Vinasse & 109.4 & {$[5]$} \\
Swaziland & Maize & Pressmud & 5.2536 & {$[88]$} \\
Swaziland & Sweet Potato & Pressmud & 13.4274 & {$[88]$} \\
India & Fish Millet & Pressmud & 3.215 & {$[89]$} \\
Mauritius & Sugarcane & Vinasse & 84.9 & {$[90]$} \\
Pakistan & Rice & Spent wash & 7.41 & {$[91]$} \\
Pakistan & Wheat & Pressmud & 5.80 & {$[47]$} \\
Pakistan & Sugarcane & Spent wash & 117.6 & {$[92]$} \\
Sudan & Sugarcane & Pressmud & 100 & {$[93]$} \\
\hline
\end{tabular}

Spent wash application increased the yield and quality of maize fodder [85]. Moreover, SCV application gave higher sugarcane yield as compared to mineral fertilizer alone (77.3 tonnes $\left.\mathrm{ha}^{-1}\right)$. In addition, [91] reported that rice growth and yield were enhanced significantly by the fertigation of distillery SW.

\subsection{Mechanisms Involved in Change of Soil Properties}

Application of organic residues having a wider C:N ratio initially immobilizes soil $\mathrm{N}$, and when mineralization sets in, nitrate is released [18]. With the application of PMC compost and other organic residues, plant height increases, which might be due to the mineralization process which releases and supplies $\mathrm{N}$ [94]. The available soil $\mathrm{N}$ increases with the application of PMC; this shows that N in PMC is readily available to the crop. This might be due to the activity of microbes involved in soil $\mathrm{N}$ transformation [5]. The mineralization of $\mathrm{N}$ fertilizers and organic residues might fulfill the requirement for $\mathrm{N}$ at plant growth stages, leading to improved plant height [94].

Results of many authors confirmed that the soil available P increases with the application of PMC compost, which might be due to the P contents present in compost which, upon decomposition of organic matter, is solubilized by the organic acid and results in an insoluble form of $\mathrm{P}$ [18]. The effect of organic acids on $\mathrm{P}$ adsorption was identified by three possible mechanisms, including competition for $\mathrm{P}$ adsorption sites, dissolution of adsorbents, and change in the adsorbents surface charge. Organic acids solubilize $\mathrm{P}$ compounds by forming complexes with metal ions. Complex formation depends upon position and number of carboxyl and phenolic functional groups [18].

The application of enriched PMC (1.25 and 2.50 tonnes $\mathrm{ha}^{-1}$ ) positively affects the availability of $\mathrm{K}$. This effect could be due to the easily degradable organics which create reducing conditions with the release of $\mathrm{K}$ ions in soil solution [95]. PMC not only improves the soil structure but also makes the salts leach down; this effect is due to the acidification of soil and availability of the soluble calcium [96]. Moreover, when applied alone or in combination with gypsum, PMC decreases the soil pH, electrical conductivity, and ESP [50]. Application of organic amendments flocculates the clay minerals, increases soil porosity, and decreases the soil bulk density, thus improving the soil structure of sodic soils [97].

The application of SCB increases the larger macroaggregates formation and reduces the microaggregates as a result of the bulk density decrease [98]. Similar results were observed by Wang et al., 2014, that organic amendments reduce the dry bulk density (11\%) and increase the total porosity (25\%) as compared to control. Unlike PMC, SCB decreases the soil particle density. Because SCB is a lower density organic matter, it decreases the mean density of the solid phase.

The application of organic manures, such as PMC, composts, etc., effectively decreases the soil $\mathrm{pH}$ as compared to control (no organic manure) [99]. Moreover, a study revealed that soil organic carbon concentration increases with the use of PMC [100]. Thus, an 
increase in $\mathrm{pH}$ can be related to the high organic carbon concentration and microbial activity. Furthermore, decomposition of organic matter produces carbonic acid which also reduces soil $\mathrm{pH}[50]$.

Sugarcane byproducts contain sugar that increases microbial decomposition; thus, $\mathrm{P}$ is released in soil [101]. It has been revealed that organic wastes release organic acids, which compete for P fixation sites, and thus reduce the soil P fixation capacity [102]. Additionally, application of PMC increases the nutrient availability due to the presence of organics, microbial activity, and soil nutrients mineralization [103].

The high level of PMC reduces the soil $\mathrm{pH}$, thus improving the availability of $\mathrm{P}$ and other micronutrients. Such changes in soil are significantly important for the better crop productivity. Therefore, as the levels of PMC increase, growth, yield, and productivity of wheat also increase [47]. Organic fertilizers have positive effects on soil properties and crop production [104]. Similar results were found that organic fertilizers not only improved physical properties of soil but also enhanced microbial activity in crop rhizosphere [47]. The rate of soil carbon sequestration can be boosted, and the role of organic matter can be elucidated for the improvement of soil health and to mitigate climate change [105].

The agronomical performance of Trigonella foenumgraecum crop increases at lower dilutions as compared to higher ones. The maximum growth was attained at $50 \%$ concentration. It might be due to the low accumulation of plant nutrients leading to better growth performance [106]. Moreover, the soil enzyme activity promoted even at high concentrations of SW [107]. The addition of organic manure stimulates the activity of microbes which results in synthesis of various soil enzymes [108]. Spent wash is a good organic amendment as it contributes huge amounts of $\mathrm{K}$ and organic matter, and considerable quantities of $\mathrm{N}$, $\mathrm{P}$, and traces of micronutrients. It also serves as a source of food for soil microorganisms which, in turn, synthesis enzymes. It involves in the conversion of native soil nutrients to plant-available forms and also forms stable chelates [34].

Spent wash contains a small amount of $\mathrm{N}$ but its application leads to an increase in the soil $\mathrm{N}$ status. It might be due to the mineralization of organic matter in SW. Moreover, SW has acidic nature and $\mathrm{HCO}_{3}$ in it which solubilize the native insoluble $\mathrm{P}$ and improves $P$ uptake [41]. It also supplies nutrients directly which might increase the microbial activity, mineralization, or chelating effect, thus releasing the native $\mathrm{N}$ and micronutrients availability. Potassium is the main component of SW; therefore, it improves the soil available $\mathrm{K}$ concentration [34]. The use of SW also increases soil CEC and the release of $\mathrm{Ca}^{2+}$ shows reduction in exchangeable $\mathrm{Na}^{+}$, thus reducing the exchangeable sodium percentage in soil [27].

Due to high BOD, the application of SW results in depletion of oxygen in soil, thus reducing the number of microorganisms initially. However, after 7 days, the population increased more than the original level. About $1 \mathrm{~kg} \mathrm{~N}, 0.2 \mathrm{~kg}$ phosphorus oxide, and $10 \mathrm{~kg}$ potassium oxide are present in every cubic meter of SW. These nutrients are easily plant available as most of them are present in soluble forms [41]. It has also been reported that the addition of SW in dry soils at the rate of $125 \mathrm{~m}^{3} \mathrm{ha}^{-1}$ increased the soil enzyme activity, such as the phosphatase, dehydrogenase, and urease. Nitrogen is in colloid form, thus acting as a slow-release fertilizer, as compared to mineral $\mathrm{N}$ sources, and classified as a liquid fertilizer that contains high $\mathrm{K}$ concentration [41].

\section{Benefits of Using Sugarcane Industries Byproducts}

Sugarcane is rich in carbohydrates; all over the world, this crop is used as food for human beings (sucrose, syrups), and is also used as animal fodder (green leaves), fertilizer (SCB and PMC), fiber (cellulitis materials), fuel (residue/waste materials), chemicals (alcohol), and binding material [18]. Bagasse is rich in nutritive value, and it can also be used as bran for ruminants during scarcity [109]. Moreover, fermentation-based products, pulp, and paper production, along with protein-enriched enzymes and cattle feed, can also be prepared using SCB [36]. Sugar industry byproducts also have positive impacts in the 
agriculture sector, as they reduce the requirement of mineral fertilizers and improve soil organic matter and crop yield [18].

The most economical application of SCB is its use as fuel in the sugar industries. The entire quantity of SCB produced in the sugar industries is used as boilers and a small proportion is used in manufacturing other products (enzymatic products, drugs, etc.). Thus, supply of SCB to bioprocessing is not limited to sugar industries [36]. Moreover, it is used as a good substrate for the growth of cellulolytic and ligninolytic microbes and a carrier for bacterial inoculants [110]. It is also reported that $\mathrm{N}$ losses can be minimized with the application of PMC and SCB (2:1 ratio) as it reduces the C:N ratio during compositing [6].

In Tamil Nadu, about 6.83 lakh tonnes of PMC were available and, as its use was unidentified, dumped in heaps near the sugar industries [111]. In India, about 600 sugar industries produce more than $8 \mathrm{M}$ tonnes of PMC, $43.8 \mathrm{Mt} \mathrm{SCB}, 7.5 \mathrm{M}$ tonnes molasses, and 7.4 Mt BA annually [18]. By encouraging the industrialist to manufacture alcohol using molasses, power generation using bagasse, compost using PMC, the disposal issues regarding these byproducts are solved by the Indian government. The organic fertilizers can also be packed and marketed with the inorganic fertilizers for specific cropping systems. PMC enhances the macro and micronutrients in the soil when used in combination with biofertilizers [18]

Molasses is a viscous liquid produced during sugar production, separated by massecuite. On average, about 23 liters of molasses is produced from one tonne of sugarcane. As it is used in the alcohol and ethanol production and has high microbial activity [18], it is an economical byproduct of sugar factories as it is used in alcohol generation, animal feed preparation, and other food products. Moreover, it is also used as a cattle feed supplement, in yeast propagation, and as a flavoring agent in food products [112]. Biomethanated SW contains many plant nutrients and can thus be used as liquid manure in agriculture [18], and it can also be used for irrigation purposes after making dilutions [86].

Bagasse ash is an effective product for the removal of phenolic compounds from wastewater [113]. It also remediates the expansive soils and it can be utilized as sand in concrete [114]. Phenanthrene present in contaminated soils can be removed using SCB isolated fungi [115] and as an absorbent for dyeing wastewater [116]. Moreover, SCV produces biochar when applied in sandy clay loam soils and reduces runoff and soil losses due to water erosion [117]. Application of SCV improves the soil's physical as well as biological properties. It can also be used for yeast production [2] (Figure 4).

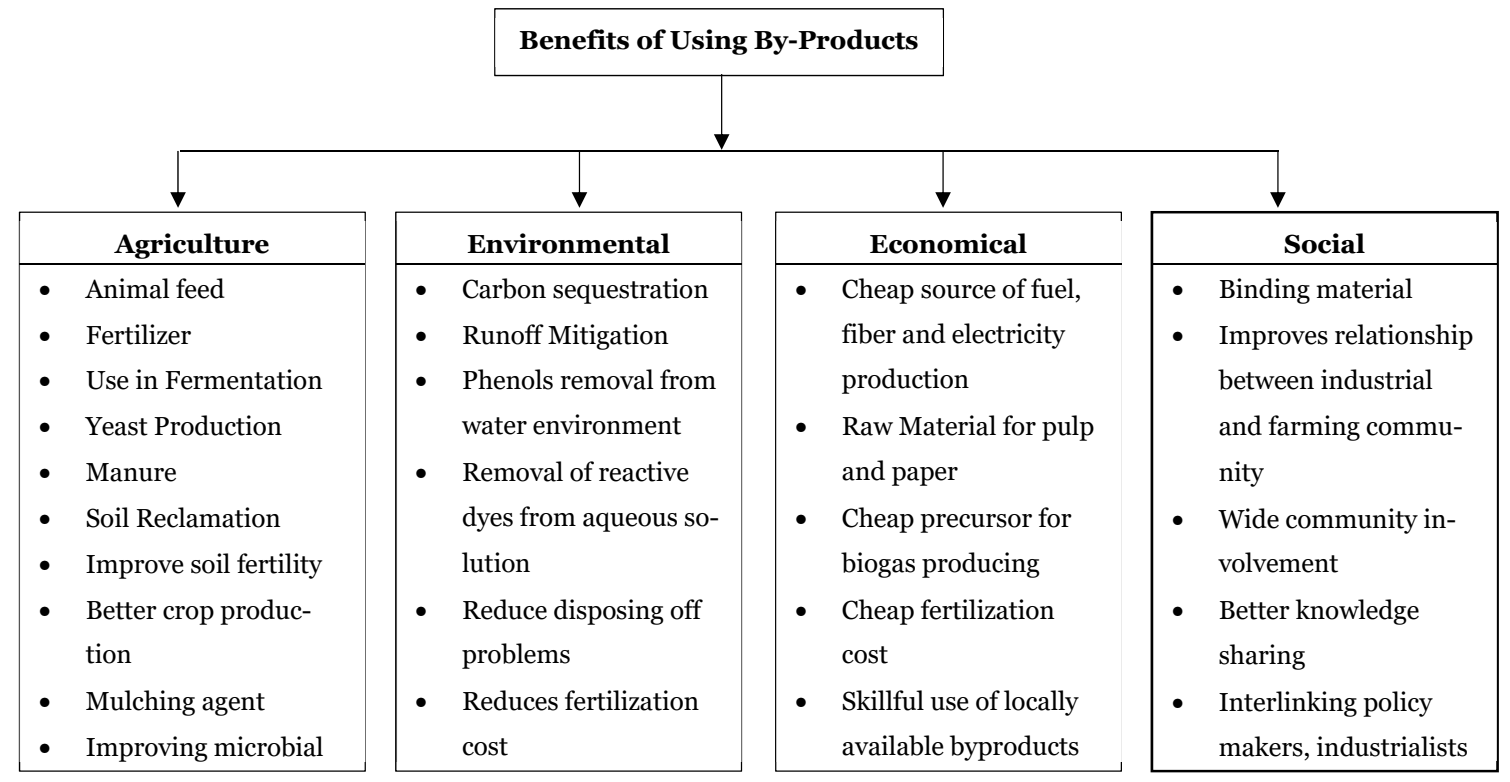

Figure 4. Benefits of using byproducts; sources [18,24,36,81,94,109,112,116,118,119]. 
To dispose of wastes and recycle the organic matter, composting is an efficient method. Pressmud cake can be used as compost for better crop yield [48] and also has mulching properties [119]. When applied with gypsum, it reduces the soil salinity and sodicity [50]. The conversion of atmospheric carbon to soil organic carbon via organic matter is known as carbon sequestration. It has been reported that it is very functional to use PMC as a mulching agent as well as compost to improve the soil carbon sequestration rates [119]. Spent wash is also a good amendment for the reclamation of alkali soils and improves crop yield [120].

Additionally, SW can be used as a fertilizer reduction agent, as its application in combination with chemical fertilizers reduces the production cost and excessive fertilizer use. Moreover, it improves the sugarcane production. It might be related to the improved soil physical, chemical, and biological properties, prevent nutrient fixation, and enhance nutrient efficiency and uptake [92]. Another study reported that the use of sugar industrial byproducts not only improved the rice productivity but also increases the cost-benefit ratio [118].

\section{Problems and Constraints}

There are a large number of sugar industries (about 579) and distilleries (about 285) in India. These mills generate 5 million tonnes PMC, 7.5 million tonnes molasses, and 45 million tonnes of SB along with sugar and alcohol [61]. Pressmud cake causes some problems due to its bulky nature and wax contents. When utilized as soil conditioner, its wax contents remain unutilized and accumulate in soil, thus degrading fertility [38]. It has been reported that PMC contains heavy metals $(\mathrm{Zn}, \mathrm{Cu}$, and $\mathrm{Pb})$ in trace amounts. Presence of these harmful chemicals in large amounts may disturb the plant growth and soil properties when used as organic amendments [65].

Sugarcane vinasse, due to its rich chemical composition, causes pollution in land and rivers near sugarcane industries [58]. A distillery that produces $100 \mathrm{~m}^{3}$ ethanol daily has a discharge of $1300 \mathrm{~m}^{3} \mathrm{SCV}$. It has a high BOD (30 to $60 \mathrm{~g} \mathrm{O}_{2} / \mathrm{L}$ ), causing high pollution load. Moreover, the direct discharge of SCV $\left(1000 \mathrm{~m}^{3} /\right.$ day $)$ and the domestic sewage output of a community of 1.5 lac people are equal [10]. The high BOD of SCV can be harmful to the aquatic life when disposed of in rivers. Due to its corrosive nature, researchers have recommended that its disposal in rivers and lakes is not a good solution [57]. Due to its high nutritional value, it is suggested to transport distillery effluents to agriculture fields through pipelines or tankers [34].

Spent wash is harmful to plant growth as its high organic and inorganic pollutants reduce the seed germination in wheat, peanut, and green gram [121]. Moreover, it reduces soil fertility and productivity. So, the untreated discharge of SW should be banned. Because it is observed that the heavy metals $\mathrm{Fe}, \mathrm{Zn}, \mathrm{Cd}, \mathrm{Cu}, \mathrm{Pb}$, and $\mathrm{Cr}$ accumulate in soil and their concentration increases in plants with the increase in SW applied concentration [106]. The accumulation of toxic elements increases with the higher concentration of SW. Approximately, $5 \%$ concentration is acceptable for better rice growth and productivity, as well as being non-hazardous to health [91]. The application of SW increased the soil salinity induced by accumulation of salts [61].

\section{Future Aspects}

All the published results are limited to short-term experiments. The effects of organic wastes in the long run are still unknown. There is a need to publish such information so that the scientific community can find the best solution for the disposal of nutrient-rich wastes. Different techniques should be introduced to the farming community and scientists should convince them to adopt such practices which would be economical for the agriculture sector. Awareness should be given to the farmers about the benefits of using organics as a cheap alternative to mineral fertilizers. Composting is feasible at a small scale, but it requires greater labor and cost when made on a large scale. So, better techniques and 
methodologies for utilizing raw wastes, recycling, or composting should be considered on a large scale.

The researchers gave different toxic levels of using organic wastes, but the harmful effects have not been discussed. The combined application of two or more sugar industry wastes is not studied properly. There is a need to study the impacts of soil application of organic amendments along with the fertigation of effluents on different crops so that the wastes can be utilized in a better way. The continuous use of different organic wastes for specific cropping sequences is also a research gap. Moreover, the impacts of industrial byproducts on crop physiological properties and the mechanism behind it needs to be addressed. The effects of industrial effluents on plant-water relations should be an aim in the future. However, it might increase the demand for organic wastes in farming communities. The proper management strategies need to be introduced to the industrialists through which they can store or transport waste to the farmers. In this way, waste will be utilized properly, on time, without causing any pollution.

\section{Conclusions}

Sugarcane crop is an important cash crop grown for the preparation of sugar and related products. The sugar industry is an agro-based industry that discharges different waste products during sugar and alcohol formation. These wastes, including SCB, BA, PMC, molasses, SCV, and SW, are produced in large amounts and their disposal causes environmental issues. Byproducts are organic and are rich in nutrients that were taken up by the sugarcane crop. This property makes these organic wastes beneficial to be utilized in agriculture with no environmental hazards. The solid wastes can replace inorganic fertilizers, while distillery effluents can also solve the problem of water shortage.

Sugar industries produce different organic byproducts that have a great potential to improve the soil's physical, chemical, and biological properties and crop productivity. It is recommended to use these organic byproducts along with mineral fertilizers to enhance the plant nutrient availability. Thus, it can contribute to minimizing the fertilizer shortage for heavy nutrient feeder crops such as sugarcane.

The organic wastes are rich in different macro and micronutrients that are essential for plant growth. The increasing cost of mineral fertilizers and the degradation of soil health is a major issue that can be efficiently solved by the use of these organics. Bagasse improves the soil properties while PMC and SCV are good sources of plant nutrients and organic matter. Distillery SW can also be used as fertilizer, but it should be diluted to certain levels to avoid heavy metal accumulation. Bagasse ash contains fewer nutrients, but it can also be utilized as fertilizer. All the wastes products have the potential to replace or minimize the use of mineral fertilizers along with the improvement of soil physical, chemical, and biological properties.

Author Contributions: Conceptualization, M.A.B., Q.-U.-A.R. and A.R.; methodology, Q.-U.-A.R., M.A.B., M.U.S. and A.R.; software, M.U.S., H.M.A. and A.F.B.; validation, M.A.B., Y.G. and A.R.; formal analysis, M.A.B., Q.-U.-A.R. and M.U.S.; data curation, Q.-U.-A.R., H.M.A.R. and M.A.B.; resources, A.R., A.F.B. and Y.G.; writing—original draft preparation, Q.-U.-A.R. and M.A.B.; writingreview and editing A.R., H.M.A.R., A.F.B., H.M.A. and Y.G.; supervision, A.R.; project administration, Y.G. and A.R.; funding acquisition, M.U.S., H.M.A. and Y.G. All authors have read and agreed to the published version of the manuscript.

Funding: This study has not received any funding.

Institutional Review Board Statement: Not applicable.

Informed Consent Statement: Not applicable.

Data Availability Statement: Not applicable.

Conflicts of Interest: The authors declare no conflict of interest. 


\section{References}

1. Sindhu, R.; Gnansounou, E.; Binod, P.; Pandey, A. Bioconversion of sugarcane crop residue for value added products-An overview. Renew. Energy 2016, 98, 203-215. [CrossRef]

2. Christofoletti, C.A.; Escher, J.P.; Correia, J.E.; Marinho, J.F.U.; Fontanetti, C.S. Sugarcane vinasse: Environmental implications of its use. Waste Manag. 2013, 33, 2752-2761. [CrossRef]

3. Chauhan, M.K.; Varun; Chaudhary, S.; Kumar, S. Samar Life cycle assessment of sugar industry: A review. Renew. Sustain. Energy Rev. 2011, 15, 3445-3453. [CrossRef]

4. Munir, A.; Ashraf, M.A.; Nasir, A.; Hensel, O.; Iqbal, M. Ergonomics and occupational health in sugar industry of Pakistan. Pak. J. Life Soc. Sci. 2012, 10, 74-79.

5. Yang, S.D.; Liu, J.X.; Wu, J.; Tan, H.W.; Li, Y.R. Effects of Vinasse and Press Mud Application on the Biological Properties of Soils and Productivity of Sugarcane. Sugar Tech. 2013, 15, 152-158. [CrossRef]

6. Meunchang, S.; Panichsakpatana, S.; Weaver, R.W. Co-composting of filter cake and bagasse; by-products from a sugar mill. Bioresour. Technol. 2005, 96, 437-442. [CrossRef] [PubMed]

7. Hati, K.M.; Biswas, A.K.; Bandyopadhyay, K.K.; Misra, A.K. Soil properties and crop yields on a vertisol in India with application of distillery effluent. Soil Tillage Res. 2007, 92, 60-68. [CrossRef]

8. Deshpande, A.N.; Kamble, B.M.; Shinde, R.B.; Gore, S.B. Effect of Primary Treated Biomethanated Spentwash on Soil Properties and Yield of Sunflower (Helianthus annuus L.) on Sodic Soil. Commun. Soil Sci. Plant Anal. 2012, 43, 730-743. [CrossRef]

9. da Silva, A.; Rossetto, R.; Bombecini, J.; Piemonte, M.; Muraoka, T. Nitrogen Mineralization from Sugarcane Vinasse. J. Plant Nutr. 2014, 37, 1227-1236. [CrossRef]

10. Spruytenburg, G.P. Vinasse pollution elimination and energy recovery. INT. Sugar J. 1982, 84, 73-74.

11. Ortegón, G.P.; Arboleda, F.M.; Candela, L.; Tamoh, K.; Valdes-Abellan, J. Vinasse application to sugar cane fields. Effect on the unsaturated zone and groundwater at Valle del Cauca (Colombia). Sci. Total Environ. 2016, 539, 410-419. [CrossRef]

12. Chowdhary, P.; Bharagava, R.N. Toxicity, beneficial aspects and treatment of alcohol industry wastewater. Emerg. Eco-Friendly Approaches Waste Manag. 2018, 83-97. [CrossRef]

13. Bashir, M.A.; Liu, J.; Geng, Y.; Wang, H.; Pan, J.; Zhang, D.; Rehim, A.; Aon, M.; Liu, H. Co-culture of rice and aquatic animals: An integrated system to achieve production and environmental sustainability. J. Clean. Prod. 2020, 249, 119310. [CrossRef]

14. Arora, N.K.; Fatima, T.; Mishra, I.; Verma, M.; Mishra, J.; Mishra, V. Environmental sustainability: Challenges and viable solutions. Environ. Sustain. 2018, 1, 309-340. [CrossRef]

15. Betts, W. Biodegradation: Natural and Synthetic Materials; Springer Science \& Business Media: Berlin, Germany, 2012.

16. Thind, H.S.; Singh, Y.; Singh, B.; Singh, V.; Sharma, S.; Vashistha, M.; Singh, G. Land application of rice husk ash, bagasse ash and coal fly ash: Effects on crop productivity and nutrient uptake in rice-wheat system on an alkaline loamy sand. Field Crop. Res. 2012, 135, 137-144. [CrossRef]

17. Shukla, S.K.; Yadav, R.L.; Awasthi, S.K.; Gaur, A. Soil Microbial Biomass Nitrogen, In Situ Respiration and Crop Yield Influenced by Deep Tillage, Moisture Regimes and N Nutrition in Sugarcane-Based System in Subtropical India. Sugar Tech. 2017, 19, 125-135. [CrossRef]

18. Dotaniya, M.L.; Datta, S.C.; Biswas, D.R.; Dotaniya, C.K.; Meena, B.L.; Rajendiran, S.; Regar, K.L.; Lata, M. Use of sugarcane industrial by-products for improving sugarcane productivity and soil health. Int. J. Recycl. Org. Waste Agric. 2016, 5, 185-194. [CrossRef]

19. Kumar, S.; Meena Asstt Professor, R.; Jinger, D.; Singh Jatav, H.; Banjara, T.; Sunil Kumar, C.; Meena, R.; Jatav, H. Use of pressmud compost for improving crop productivity and soil health. Int. J. Chem. Stud. IJCS 2017, 5, 384-389.

20. Gupta, R.K. Evaluation of press mud cake as a source of nitrogen and phosphorus for rice-Wheat cropping system in the Indo-Gangetic plains of India. Biol. Fertil. Soils 2008, 44, 755-762. [CrossRef]

21. Prado, R.D.M.; Caione, G.; Campos, C.N.S. Filter cake and vinasse as fertilizers contributing to conservation agriculture. Appl. Environ. Soil Sci. 2013, 2013, 1-8. [CrossRef]

22. Kalaivanan, D.; Omar Hattab, K. Recycling of sugarcane industries byproducts for preparation of enriched pressmud compost and its influence on growth and yield of rice (Oryza sativa L.). Int. J. Recycl. Org. Waste Agric. 2016, 5, 263-272. [CrossRef]

23. Sarwar, G.; Hussain, N.; Schmeisky, H.; Muhammad, S. Use of compost an environment friendly technology for enhancing rice-wheat production in Pakistan. Pak. J. Bot. 2007, 39, 1553-1558.

24. Jamil, M.; Qasim, M.; Zia, M.S. Utilization of pressmud as organic amendment to improve physico-chemical characteristics of calcareous soil under two legume crops. J. Chem. Soc. Pak. 2008, 30, 577-583.

25. Nawaz, A.; Farooq, M.; Nadeem, F.; Siddique, K.H.M.; Lal, R. Rice-wheat cropping systems in South Asia: Issues, options and opportunities. Crop Pasture Sci. 2019, 70, 395-427. [CrossRef]

26. Gleick, P.H.; Cooley, H. Freshwater Scarcity. Annu. Rev. Environ. Resour. 2021, 46, 319-348. [CrossRef]

27. Hassan, M.U.; Aamer, M.; Chattha, M.U.; Haiying, T.; Khan, I.; Seleiman, M.F.; Rasheed, A.; Nawaz, M.; Rehman, A.; Aslam, M.T.; et al. Sugarcane distillery spent wash (Dsw) as a bio-nutrient supplement: A win-win option for sustainable crop production. Agronomy 2021, 11, 183. [CrossRef]

28. Gupta, A.; Sharma, N.K.; Bhardwaj, S.; Srivastava, P.K. Treated waste water as an alternative to fresh water irrigation with improved crop production. In Agricultural Water Management; Academic Press: Cambridge, MA, USA, $2021 ;$ pp. 49-65. 
29. Meghana, M.; Shastri, Y. Sustainable valorization of sugar industry waste: Status, opportunities, and challenges. Bioresour. Technol. 2020, 303, 122929. [CrossRef] [PubMed]

30. Ramalho, J.; Sobrinho, N. Metais Pesados em Solos Cultivados Com Cana-de-Açúcar Pelo Uso de Resíduos Agroindustriais. Braz. J. For. Enviroment 2001, 8, 120-129.

31. Li, Y.R.; Yang, L.T. Sugarcane Agriculture and Sugar Industry in China. Sugar Tech. 2015, 17, 1-8. [CrossRef]

32. Segura-Muñoz, S.I.; Da Silva Oliveira, A.; Nikaido, M.; Trevilato, T.M.B.; Bocio, A.; Takayanagui, A.M.M.; Domingo, J.L. Metal levels in sugar cane (Saccharum spp.) samples from an area under the influence of a municipal landfill and a medical waste treatment system in Brazil. Environ. Int. 2006, 32, 52-57. [CrossRef]

33. Su, T.-M.; Li, Y.-R.; Wei, G.-P.; Jiang, Z.-P. Effect of sugarcane vinasse on soil physicochemical properties and oxidoreductase enzymes. Chin. J. Eco Agric. 2009, 17, 1106-1110. [CrossRef]

34. Baskar, M.; Kayalvizhi, C.; Bose, M.S.C. Eco-Friendly Utilisation of Distillery Effluent in Agriculture-A Review. Agric. Rev. 2003, 24, 16-30.

35. Verma, D.; Gope, P.C.; Maheshwari, M.K.; Sharma, R.K. Bagasse fiber composites-A review. J. Mater. Environ. Sci. 2012, 3, 1079-1092.

36. Pandey, A.; Soccol, C.R.; Nigam, P.; Soccol, V.T. Biotechnological potential of agro-industrial residues. I: Sugarcane bagasse. Bioresour. Technol. 2000, 74, 69-80. [CrossRef]

37. Gupta, N.; Tripathi, S.; Balomajumder, C. Characterization of pressmud: A sugar industry waste. Fuel 2011, 90, 389-394. [CrossRef]

38. Bhosale, P.R.; Chonde, S.G.; Nakade, D.B.; Raut, P.D. Studies on Physico-Chemical Characteristics of Waxed and Dewaxed Pressmud and Its Effect on Water Holding Capacity of Soil. ResearchGate Net. 2012, 1, 35-41.

39. Robertiello, A. Upgrading of agricultural and agro-industrial wastes: The treatment of distillery effluents (vinasses) in Italy. Agric. Wastes 1982, 4, 387-395. [CrossRef]

40. España-Gamboa, E.; Mijangos-Cortes, J.; Barahona-Perez, L.; Dominguez-Maldonado, J.; Hernández-Zarate, G.; Alzate-Gaviria, L. Vinasses: Characterization and treatments. Waste Manag. Res. 2011, 29, 1235-1250. [CrossRef] [PubMed]

41. Rajkishore, S.K.; Vignesh, N.S. Distillery Spentwash in the context of crop production-A review. Bioscan 2012, 7, 369-375.

42. Yadvinder-Singh; Bijay-Singh; Ladha, J.K.; Khind, C.S.; Khera, T.S.; Bueno, C.S. Effects of Residue Decomposition on Productivity and Soil Fertility in Rice-Wheat Rotation. Soil Sci. Soc. Am. J. 2004, 68, 854-864. [CrossRef]

43. Shinde, B.N.; Takate, A.S.; Patil, A.S. Mineralization of Nitrogen from Spent Wash (Distillery Effluent) Solids and Spent Wash-Press Mud Compost. Maharashtra Agri. Univ. 1994, 19, 441-442.

44. Huang, Z.; Wang, N.; Zhang, Y.; Hu, H.; Luo, Y. Effect of mechanical activation pretreatment on the properties of sugarcane bagasse/poly(vinyl chloride) composites. Compos. Part A Appl. Sci. Manuf. 2012, 43, 114-120. [CrossRef]

45. Khosravi Darani, K.; Zoghi, A.; Alavi, S.A.; Fatemi, S.S.A. Application of Plackett Burman design for citric acid production from pretreated and untreated wheat straw. Iran. J. Chem. Chem. Eng. 2008, 27, 91-104.

46. Alavéz-Ramírez, R.; Montes-García, P.; Martínez-Reyes, J.; Altamirano-Juárez, D.C.; Gochi-Ponce, Y. The use of sugarcane bagasse ash and lime to improve the durability and mechanical properties of compacted soil blocks. Constr. Build. Mater. 2012, 34, 296-305. [CrossRef]

47. Khan, M.J.; Khan, M.Q.; Zia, M.S. Sugar industry press mud as alternate organic fertiliser source. Int. J. Environ. Waste Manag. 2012, 9, 41-55. [CrossRef]

48. Diaz, P. Consequences of Compost Press Mud as Fertilizers. DJ Int. J. Adv. Microbiol. Microbiol. Res. 2016, 1, 28-32. [CrossRef]

49. Bhatnagar, A.; Kesari, K.K.; Shurpali, N. Multidisciplinary Approaches to Handling Wastes in Sugar Industries. Water. Air. Soil Pollut. 2016, 227, 1-30. [CrossRef]

50. Negim, O. Effect of Addition Pressmud and Gypsum by Product to Reclamation of Highly Calcareous Saline Sodic Soil. Am. Assoc. Sci. Technol. J. Environ. I. 2016, 1, 76-84.

51. Salama, Y.; Chennaoui, M.; Amraoui, M.E.; Mountadar, M. A Review of Compost Produced from Biological Wastes: Sugarcane Industry Waste. Int. J. Food Sci. Biotechnol. 2016, 1, 24-37. [CrossRef]

52. Marafon, A.C.; Salomon, K.R.; Amorim, E.L.C.; Peiter, F.S. Use of sugarcane vinasse to biogas, bioenergy, and biofertilizer production. In Sugarcane Biorefinery, Technology and Perspectives; Elsevier: Amsterdam, The Netherlands, 2019; pp. 179-194, ISBN 9780128142363.

53. Moran-Salazar, R.G.; Sanchez-Lizarraga, A.L.; Rodriguez-Campos, J.; Davila-Vazquez, G.; Marino-Marmolejo, E.N.; Dendooven, L.; Contreras-Ramos, S.M. Utilization of vinasses as soil amendment: Consequences and perspectives. Springerplus 2016, 5, 1007. [CrossRef] [PubMed]

54. Jiang, Z.P.; Li, Y.R.; Wei, G.P.; Liao, Q.; Su, T.M.; Meng, Y.C.; Zhang, H.Y.; Lu, C.Y. Effect of Long-Term Vinasse Application on Physico-chemical Properties of Sugarcane Field Soils. Sugar Tech. 2012, 14, 412-417. [CrossRef]

55. Rajagopal, V.; Paramjit, S.M.; Suresh, K.P.; Yogeswar, S.; Nageshwar, R.D.V.K.; Avinash, N. Significance of vinasses waste management in agriculture and environmental quality- Review. Afr. J. Agric. Res. 2014, 9, 2862-2873. [CrossRef]

56. Reis, C.E.R.; Hu, B. Vinasse from sugarcane ethanol production: Better treatment or better utilization? Front. Energy Res. 2017, 5, 7.

57. Nakashima, R.N.; de Oliveira Junior, S. Comparative exergy assessment of vinasse disposal alternatives: Concentration, anaerobic digestion and fertirrigation. Renew. Energy 2020, 147, 1969-1978. [CrossRef] 
58. Algur, Ö.F.; Kadioğlu, A. The effects of vinasse on the growth, biomass and primary productivity in pea (Pisum sativum) and sunflower (Helianthus annuus). Agric. Ecosyst. Environ. 1992, 39, 139-144. [CrossRef]

59. Cortez, L.A.B.; Perez, L.E.B. Experiences on vinasse disposal. Part III: Combustion of vinasse-\#6 fuel oil emulsions. Braz. J. Chem. Eng. 1997, 14, 9-18. [CrossRef]

60. Naik, N.M.; Jagadeesh, K.S.; Alagawadi, A.R. Microbial decolorization of spentwash: A review. Indian J. Microbiol. 2008, 48, 41-48. [CrossRef] [PubMed]

61. Mahimairaja, S.; Bolan, S.N. Problems and prospects of agricultural use of distillery spentwash in India. Magnesium 2004, 1715, 5-9.

62. Fito, J.; Tefera, N.; Van Hulle, S.W.H. Sugarcane biorefineries wastewater: Bioremediation technologies for environmental sustainability. Chem. Biol. Technol. Agric. 2019, 6, 1-13. [CrossRef]

63. Garcia, C.F.H.; de Souza, R.B.; de Souza, C.P.; Christofoletti, C.A.; Fontanetti, C.S. Toxicity of two effluents from agricultural activity: Comparing the genotoxicity of sugar cane and orange vinasse. Ecotoxicol. Environ. Saf. 2017, 142, 216-221. [CrossRef] [PubMed]

64. Tiwari, R.; Nema, G. Response of sugarcane (Saccharum officinarum) to direct and residual effect of pressmud and nitrogen. Indian J. Agric. Sci. 1999, 69, 644647.

65. Kumar, V.; Chopra, A.K. Effects of sugarcane pressmud on agronomical characteristics of hybrid cultivar of eggplant (Solanum melongena L.) under field conditions. Int. J. Recycl. Org. Waste Agric. 2016, 5, 149-162. [CrossRef]

66. Bangar, K.S.; Parmar, B.B.; Maini, A. Effect of nitrogen and pressmud cake application on yield and uptake of N, P and K by sugarcane (Saccharum officinarum L.). Crop Res. 2000, 19, 198-203.

67. Moberly, P.; Meyer, J. Filter cake. A field and glasshouse evaluation. Proc. South Afr. Sugar Technol. Assoc. 1978, 52, 131-136.

68. Rodella, A.A.; Silva, L.C.F.; Filho, J.O. Effects of filter cake applications on sugarcane yields in Brazil. Sugar J. 1991, 54, 22-24.

69. Fischer, R.A.; Byerlee, D.; Edmeades, G.O. Can technology deliver on the yield challenge to 2050? In Proceedings of the FAO Expert Meeting on How to Feed the World in 2050, Rome, Italy, 24-26 June 2009; pp. 1-48. [CrossRef]

70. Iqbal, N.; Khan, N.A.; Ferrante, A.; Trivellini, A.; Francini, A.; Khan, M.I.R. Ethylene role in plant growth, development and senescence: Interaction with other phytohormones. Front. Plant Sci. 2017, 8, 475. [CrossRef] [PubMed]

71. Zeng, X.P.; Zhu, K.; Lu, J.M.; Jiang, Y.; Yang, L.T.; Xing, Y.X.; Li, Y.R. Long-term effects of different nitrogen levels on growth, yield, and quality in sugarcane. Agronomy 2020, 10, 353. [CrossRef]

72. Gemtos, T.A.; Chouliaras, N.; Marakis, S. Vinasse rate, time of application and compaction effect on soil properties and durum wheat crop. J. Agric. Eng. Res. 1999, 73, 283-296. [CrossRef]

73. Chandraju, S.; Basavaraju, H.C.; Chidankumar, C.S. Impact of distillery spentwash irrigation on nutrients of some fruits: An investigation. Nat. Environ. Pollut. Technol. 2009, 8, 301-306.

74. Ahmed, M.; Qureshi, J.; Nergis, Y.; Shareef, M. Environmental Impacts of Spent Wash on Soil Quality. Int. J. Econ. Environ. Geol. 2015, 6, 15-20.

75. Pathak, H.; Joshi, H.C.; Chaudhary, A.; Chaudhary, R.; Kalra, N.; Dwiwedi, M.K. Soil amendment with distillery effluent for wheat and rice cultivation. Water. Air. Soil Pollut. 1999, 113, 133-140. [CrossRef]

76. Malaviya, P.; Sharma, A. Effect of distillery effluent on yield attributes of Brassica napus L. J. Environ. Biol. 2011, 32, 385-389. [PubMed]

77. Chidankumar, C.S.; Chandraju, S. Impact of irrigation of distillery spentwash on the nutrients of pulses in untreated and treated soil. Sugar Tech. 2008, 10, 314-318. [CrossRef]

78. Pant, D.; Adholeya, A. Biological approaches for treatment of distillery wastewater: A review. Bioresour. Technol. 2007, 98, 2321-2334. [CrossRef] [PubMed]

79. Alvarez-Campos, O.; Lang, T.A.; Bhadha, J.H.; McCray, J.M.; Glaz, B.; Daroub, S.H. Biochar and mill ash improve yields of sugarcane on a sand soil in Florida. Agric. Ecosyst. Environ. 2018, 253, 122-130. [CrossRef]

80. Sarimong, R.T.; Sanchez, P.B.; Badayos, R.B.; Paterno, E.S.; Pompe, P.C. Effect of organic amendments and microbial inoculant on nitrogen, phosphorus and potassium use efficiency of sugarcane under acid typic hapludand. J. Int. Soc. Southeast Asian Agric. Sci. 2017, 23, 114-124.

81. Raza, Q.U.; Bashir, M.A.; Rehim, A.; Raza, H.M. Role of sugarcane industrial byproducts on soil physicochemical properties and metal accumulation in rice. Environ. Sci. Pollut. Res. 2021, 26, 1. [CrossRef]

82. Sarwar, M.A.; Ibrahim, M.; Tahir, M.; Ahmad, K.; Khan, Z.I. Appraisal of Pressmud and Inorganic Fertilizers on Soil Properties, Yield and Sugarcane Quality. Pak. J. Bot. 2010, 42, 1361-1367.

83. Omar Hattab, K.; Natarajan, K.; Gopalaswamy, A. Influence of different organic manures on yield and N use efficiency of rice. J. Indian Soc. Soil Sci. 1998, 46, 239-242.

84. Jeyabal, A.; Kuppuswamy, G. Recycling of organic wastes for the production of vermicompost and its response in rice-Legume cropping system and soil fertility. Eur. J. Agron. 2001, 15, 153-170. [CrossRef]

85. Patil, G.; Shinde, B. Effect of spent-wash (distillery effluent), spent-slurry and pressmud composts on maize. J. Indian Soc. Soil Sci. 1995, 43, 700-702.

86. Nath, K.; Singh, D.; Sharma, Y.K. Combinatorial effects of distillery and sugar factory effluents in crop plants. J. Environ. Biol. 2007, 28, 577-582. [PubMed]

87. Gonfa, A.; Bedadi, B.; Argaw, A. Effect of bagasse ash and filter cake amendments on wheat (Triticum turgidum L.var. durum) yield and yield components in nitisol. Int. J. Recycl. Org. Waste Agric. 2018, 7, 231-240. [CrossRef] 
88. Ossom, E.M. Response of Ipomoea batatas (L.) Lam. to Soil Fertilization with Filter Cake. Trans. Ill. State Acad. Sci. 2007, 100, 197-208.

89. Rangaraj, T.; Somasundaram, E.; Amanullah, M.M.; Thirumurugan, V.; Ramesh, S.; Ravi, S. Effect of agro-industrial wastes on soil properties and yield of irrigated finger millet (Eleusine coracana L. Gaertn) in coastal soil. Res. J. 2007, 3, 153-156.

90. Soobadar, A.; Ng Kee Kwong, K.F.R. Impact of High Rates of Vinasse on Some Pertinent Soil Characteristics and on Sugarcane Yield in Mauritius. J. Sustain. Agric. 2012, 36, 36-53. [CrossRef]

91. Naveed, S.; Rehim, A.; Imran, M.; Anwar, M.F.; Hussain, S. Effect of distillery spentwash fertigation on crop growth, yield, and accumulation of potentially toxic elements in rice. Environ. Sci. Pollut. Res. 2018, 25, 31113-31124. [CrossRef]

92. Nawaz, M.; Khan, S.; Ali, H.; Ijaz, M.; Chattha, M.U.; Hassan, M.U.; Irshad, S.; Hussain, S.; Khan, S. Assessment of Environmentfriendly Usage of Spent Wash and Its Nutritional Potential for Sugarcane Production. Commun. Soil Sci. Plant Anal. 2019, 50, 1239-1249. [CrossRef]

93. Elsayed, M.T.; Babiker, M.H.; Abdelmalik, M.E.; Mukhtar, O.N.; Montange, D. Impact of filter mud applications on the germination of sugarcane and small-seeded plants and on soil and sugarcane nitrogen contents. Bioresour. Technol. 2008, 99, 4164-4168. [CrossRef] [PubMed]

94. Khan, A.H.; Singh, A.K.; Singh, S.; Zaidi, N.W.; Singh, U.S.; Haefele, S.M. Response of Salt-Tolerant Rice Varieties to Biocompost Application in Sodic Soil of Eastern Uttar Pradesh. Am. J. Plant Sci. 2014, 5, 7-13. [CrossRef]

95. Shivam, R.; Singh, S. International Journal of Scientific and Research Publications. Int. J. Sci. Res. Publ. $2015,5,369-372$.

96. Haq, I.H.; Hattak, S.G.K.; Ahman, H.R.; Li, A.A.; Alim, M.S. Effect of Various Amendments on the Yield of Rice Crop under Saline-Sodic Conditions in Mardan/Swabi Districts. Int. J. Agric. Biol. 2001, 3, 2000-2002.

97. Wang, L.; Sun, X.; Li, S.; Zhang, T.; Zhang, W.; Zhai, P. Application of organic amendments to a coastal saline soil in north China: Effects on soil physical and chemical properties and tree growth. PLoS ONE 2014, 9, 1-9. [CrossRef]

98. El-Halim, A.A.A.; Kumlung, A. Modification of sandy soil hydrophysical environment through bagasse additive under laboratory experiment. Int. Agrophysics 2015, 29, 101-106. [CrossRef]

99. Bahadur, L.; Tiwari, D.D.; Mishra, J.; Gupta, B.R. Nutrient Management in Rice-Wheat Sequence under Sodic Soil. J. Indian Soc. Soil Sci. 2013, 61, 341-346.

100. Shehzadi, S.; Shah, Z.; Mohammad, W. Impact of organic amendments on soil carbon sequestration, water use efficiency and yield of irrigated wheat. Base 2017, 21, 36-49. [CrossRef]

101. Eghball, B.; Binford, G.D.; Baltensperger, D.D. Phosphorus Movement and Adsorption in a Soil Receiving Long-Term Manure and Fertilizer Application. J. Environ. Qual. 1996, 25, 1339-1343. [CrossRef]

102. Dotaniya, M. Crop Residue Management in Rice-Wheat Cropping System; Lap Lambert Academic Publisher: Saarbrücken, Germany, 2012; p. 116.

103. Rakkiyappan, P.; Thangavelu, S.; Malathi, R.; Radhamani, R. Effect of biocompost and enriched pressmud on sugarcane yield and quality. Sugar Tech. 2001, 3, 92-96. [CrossRef]

104. Verma, B.C.; Pramanik, P.; Bhaduri, D. Organic fertilizers for sustainable soil and environmental management. In Nutrient Dynamics for Sustainable Crop Production; Springer: Singapore, 2019; pp. 289-313, ISBN 9789811386602.

105. Aryal, J.P.; Sapkota, T.B.; Khurana, R.; Khatri-Chhetri, A.; Rahut, D.B.; Jat, M.L. Climate change and agriculture in South Asia: Adaptation options in smallholder production systems. Environ. Dev. Sustain. 2020, 22, 5045-5075. [CrossRef]

106. Kumar, V.; Chopra, A.K. Fertigation effect of distillery effluent on agronomical practices of Trigonella foenum-graecum L. (Fenugreek). Environ. Monit. Assess. 2012, 184, 1207-1219. [CrossRef] [PubMed]

107. Kalaiselvi, P.; Mahimairaja, S. Effect of biomethanated spent wash on soil enzymatic activities. Bot. Res. Int. 2009,2 , $267-272$.

108. Sekaran, U.; Sandhu, S.S.; Qiu, Y.; Kumar, S.; Gonzalez Hernandez, J.L. Biochar and manure addition influenced soil microbial community structure and enzymatic activities at eroded and depositional landscape positions. L. Degrad. Dev. 2020, 31, 894-908. [CrossRef]

109. So, S.; Cherdthong, A.; Wanapat, M. Improving sugarcane bagasse quality as ruminant feed with Lactobacillus, cellulase, and molasses. J. Anim. Sci. Technol. 2020, 62, 648-658. [CrossRef]

110. Saranraj, P.; Stella, D. Composting of sugar mill wastes: A Review. World Appl. Sci. J. 2014, 31, 2029-2044. [CrossRef]

111. Jones, J.B.; Tirado-Corbalá, R. Plant Nutrition and Soil Fertility Manual, 2nd ed.; CRC Press: Boca Raton, FL, USA, 2012.

112. Havekes, C.D.; Duffield, T.F.; Carpenter, A.J.; DeVries, T.J. Effects of molasses-based liquid feed supplementation to a high-straw dry cow diet on feed intake, health, and performance of dairy cows across the transition period. J. Dairy Sci. 2020, 103, 5070-5089. [CrossRef]

113. Gallo, Y.M.; de Hoces, F.M.C.; Rico, I.L.R.; Lara, M.Á.M.; García, J.O.P. Adsorption kinetics of phenol from aqueous solution using sugarcane bagasse ash as low-cost adsorbent material. ITEGAM J. Eng. Technol. Ind. Appl. 2020, 6, 21-26. [CrossRef]

114. Paris, J.M.; Roessler, J.G.; Ferraro, C.C.; Deford, H.D.; Townsend, T.G. A review of waste products utilized as supplements to Portland cement in concrete. J. Clean. Prod. 2016, 121, 1-18. [CrossRef]

115. Pourfadakari, S.; Jorfi, S.; Roudbari, A.; Javid, A.; Talebi, S.S.; Ghadiri, S.K.; Yousefi, N. Optimization of electro-kinetic process for remediation of soil contaminated with phenanthrene using response surface methodology. Environ. Sci. Pollut. Res. 2021, 28, 1006-1017. [CrossRef] 
116. Gita, S.; Prakash Shukla, S.; Deshmukhe, G.; Singh, A.R.; Gon Choudhury, T.; Singh, A.K. Adsorptionbiodegradation coupled remediation process for the efficient removal of a textile dye through chemically functionalized sugarcane bagasse. Water Environ. Res. 2021, 93, 2223-2236. [CrossRef]

117. Sadeghi, S.H.; Hazbavi, Z.; Harchegani, M.K. Controllability of runoff and soil loss from small plots treated by vinasse-produced biochar. Sci. Total Environ. 2016, 541, 483-490. [CrossRef]

118. Raza, Q.A.; Bashir, M.A.; Rehim, A.; Hye, M.Z.; Tarar, Z.H. Achieving Sustainable Rice Production with the Application of Sugarcane Industrial by-Products. Pak. J. Agric. Agric. Eng. Vet. Sci. 2021, 37, 1-10. [CrossRef]

119. Padalkar, R.C.; Raut, P.D. Assessment of soil carbon level after application of pressmud and mulching regarding soil carbon sequestration. Nat. Environ. Pollut. Technol. 2016, 15, 601-604.

120. Deshpande, A.N.; Kamble, B.M.; Said, L.B.; Wadekar, S.M. Effect of Primary Biomethanated Spentwash on Soil Properties, Nutrient Uptake, and Yield of Wheat on Sodic Soil. Commun. Soil Sci. Plant Anal. 2017, 48, 963-976. [CrossRef]

121. Goli, J.; Sahu, O. Effect of Distillery Industry Effluent on Fertility of Soil and Crops. Int. J. Soil Crop Sci. 2014, 2, 39-45. 